\title{
Estimation of Trace Elements in Fly Ash Released from Coal Combustion
}

\author{
Ali A. Eltayeib \\ Department of Chemistry, Faculty of Science, Kordofan University, Elobeid, Sudan \\ Email: alieltayeib@yahoo.com
}

Received 19 April 2014; revised 21 May 2014; accepted 19 June 2014

Copyright (C) 2014 by author and OALib.

This work is licensed under the Creative Commons Attribution International License (CC BY). http://creativecommons.org/licenses/by/4.0/

(c) (i) Open Access

\section{Abstract}

Qingshan Thermoelectric Plant located in Wuhan City, Hubei Province, China, and it uses coal as a fuel. Coal combustion generates not only gaseous pollutants like $\mathrm{SO}_{2}$ and $\mathrm{NO}_{\mathrm{x}}$ but also toxic and heavy metals to the atmosphere. From the environmental point of view, the determination and speciation of trace toxic and heavy metals released from coal combustion are very important. In this work, the atomic spectroscopic methods for determination of some trace elements were first established. Graphite furnace atomic absorption spectrometry (GFAAS) method was used to determine the trace $\mathrm{Pb}$ in standard reference material SRM 8322 (fly ash from combustion of pulverized coal). The hydride generation atomic absorption spectrometry coupled with flow injection analysis (HGAAS-FIA) was used to analyze the concentration of As in SRM 8322 and the ICP-AES for determination of trace elements $\mathrm{Co}, \mathrm{Ni}, \mathrm{Cu}, \mathrm{Cr}$, etc. For the laboratory research work, all the coal samples were digested with a mixture of acids $\left(\mathrm{HNO}_{3}-\mathrm{HF}-\mathrm{HCLO}_{4}\right)$ after burned at $650^{\circ} \mathrm{C}$ for one hour. Based on the establishment of atomic spectroscopic determination methods Tessier sequential speciation and separation methods were used in the studies of speciation distribution of some heavy metals in fine particles released from coal combustion of Qingshan Thermoelectric Plant. The transition elements in two samples from Qingshan Thermoelectric Plant (with different combustion condition) were extracted into five fractions by sequential extraction. In each fraction a suitable reagents with an optimum $\mathrm{pH}$ and time were used. Centrifugate separation of liquid part from the solid part was used after each fraction, the liquid part is taken for analysis and the solid part was extracted with a suitable reagents for the next fraction and the reaction continued for certain time. This procedure was done for the five fractions (exchangeable, carbonate bounded, Fe-Mn oxide bounded, organic matter bounded and residual). The experiment of the stimulant acid rain reacted with coal ash were also done in order to evaluate the transformation of these trace elements into water system after the fine particles of coal ash act with acid rain. The results showed that most parts of the metal in particles are stable. In order to study the distribution tendency of trace elements in coal, the separation of different coal particles were done using organic solvent extraction and gravity settlement method. The results showed that different trace elements had different distribution tendency in coal.

\section{Keywords}

Trace Elements, Fly Ash, Graphite Furnace, Sequential Extraction 


\section{Introduction}

Combustion of coal is a potential source of several trace element emissions to the atmosphere including heavy metals. Coal is the most abundant fossil fuel used throughout the world for production of electricity. Coal-fired power plant releases to the environment $\mathrm{SO}_{2}$ and $\mathrm{NO}_{\mathrm{x}}$ as well as $\mathrm{CO}_{2}$ and $\mathrm{N}_{2} \mathrm{O}_{5}$. Arsenic, cadmium, lead and mercury are highly toxic to most biological systems at concentration at critical levels. Different trace elements in coal have different distribution characters in coal combustion. Inorganic matrices were shown to alter the concentration and occurrence of semi-volatile trace elements (As, Sb, Se) in the gas phase and these observations were attributed to specific interaction of ionic trace element species with cationic matrices [1]. The distribution and concentration of trace elements in coal are important from the environmental point of view, since they predict prediction of the behavior of these elements as they are released into the atmosphere when the coal is burned [2]. The trace elements associated with sulfide and organic matter generally enriched in fly ash because they are known by their volatilization during coal combustion. Volatilization probably does not occur in trace elements associated with the alumino-silicate minerals. The enrichment of trace elements on the ashes is a function of the particle size. Natusch et al. [3] explained this enrichment through the volatilization condensation mechanism based on the higher concentration of trace elements in the fly ash (especially on surface particles) emitted into the atmosphere, when compared with those collected by controlled equipment (ex: electrostatic precipitator). The mode of occurrence of trace elements in coal is very important in the understanding of mechanisms by which trace elements are enriched in fly ash and to predict the behavior of elements during coal combustion [4]. Finer particles have been shown in epidemiological studies to be more strongly associated with the adverse health outcomes than coarser particles. The effects of fine particles on health were reviewed from the points influence of composition, and the factors that determine trace element release and emission from full scale plants [5]. Haihan et al. [6] explained the dissolved atmospheric iron deposition fluxes and their effect on the biogeochemistry at the ocean surface by the source, environmental $\mathrm{pH}$, iron speciation, and solar radiation. Graphite furnace atomic absorption spectrometry (GFAAS) is one of the most sensitive techniques for the determination of a large number of elements with the detection limits in the $\mu \mathrm{g} \cdot \mathrm{l}^{-1}-\mathrm{ng} \cdot \mathrm{l}^{-1}$ range. In samples of complex composition, however, matrix effects can have a significant influence on the performance of GFAAS. While interferences may be overcome to various degrees by applying the "stabilized-temperature platform furnace” (STPF) concept [7] using chemical modification, atomization from a L'vov platform, signal evaluation by integrating absorbance overtime and a powerful background correction technique applying the Zeeman effect, separation of the analyte element from the matrix will undoubtedly be even more effective in avoiding matrix interferences. Flow injection (FI) as a micro sample introduction system offers some distinct advantages over manual batch-type procedures for analyte pre-concentration and separation, such as fully automated sample management and operation in a closed system [8]. On-line pre-concentration of trace elements with ion-exchange [9] or sorbent-extraction [10] [11] columns using FI techniques has effectively enhanced the sensitivity and selectivity of flame AAS. The application of FI column pre-concentration to GFAAS, however, has been limited owing to the discrete non-flow through nature of this technique. Off-line FI pre-concentration procedures involving the collection of the eluate in a vessel followed by conventional sample introduction [12] [13] have the disadvantages of being laborious and time consuming, with a high risk of contamination from the equipment and the laboratory air, calling for a clean-room environment. In addition, by collection the entire eluate volume and introducing only a small part of it (10\% - 20\% maximum) into the furnace tube, the effect of the pre-concentration is in part lost by the inherent dilution and limitation to small sample volumes. Fang et al. [14] were the first to describe an on-line FI sorbent extraction pre-concentration system for GFAAS with lead as model trace element. A direct automated method without any matrix separation or pre-concentration is desirable for the routine analysis of water for trace elements and of highly mineralized water samples. The method should be free from interferences over the concentration range of the concomitant species [15]. For public health protection, the analytical method used should be able to measure $10 \%$ of the maximum allowable contaminant level in the drinking water [16]. GFAAS is one of the few analytical techniques which fulfills these requirements, and is the method most frequently used. GFAAS was used for the determination of trace impurities from large size sam- 
ples of uranium metal and thorium oxide using a small column of chelx-100 [17]. Multi-element GFAAS was used for the determination of minor and trace amount of elements in silicate rock, lake and stream sediments [18]. Co-precipitation with metal hydroxide is a useful pre-concentration technique in trace analysis and radiochemistry [19]-[21] with a simple procedure, traces of heavy metals in an aqueous solution are simultaneously and quantitatively collected on the gathering precipitates. Among the metal hydroxides used for co-precipitation was Tin(IV) hydroxide for the determination of trace heavy metals by GFAAS [22]. GFAAS has been used for the direct determination of the pro-oxidant $\mathrm{Cu}, \mathrm{Fe}$ and $\mathrm{Ni}$ in crude and refined edible oils [23] and fats. An ultrasonic slurry sampler with GFAAS was used for the determination of particulate elements in edible oils and fats [24]. For determination of the elements the application of hydride generation (HG) techniques to AAS is well established [25]-[27]. Flow injection analysis (FIA) has been widely used, mainly in the field of colorimetry [28], also it was applied as an automatic sample injection technique for flame AAS [29]-[31]. It was used as an on-line pretreatment method for AAS to concentrate by chelate resin [32] or solvent extraction [33] and to remove interferences by ion-exchange [34]. The FIA technique combined with the gas-segmentation method [35] is applied for the HG-AAS of arsenic, antimony, bismuth, selenium, and tellurium, and its applicability for environmental analysis was exhibited by determining these elements in several NBS SRMS. One of the characteristics of the FIA in contrast to the conventional continuous flow analysis is the injection of a discrete sample into a continuous carrier flow without gas segmentation, which enabled the rapid and precise determination by using transient signals [36]. The effect of injection rate on the peak height in several combinations of the sample and $\mathrm{NaBH}_{4}$ solutions was shown, and the effect of $\mathrm{pH}$ on the peak height absorbance of several arsenic and selenium species was investigated [37]. For the determination of antimony and arsenic in copper and steel using FIHGAAS, L-cysteine was used as a reducing and releasing agent [38]. Several experimental procedures, varying in manipulative complexity, have been proposed for determining the speciation of particulate trace metals. These procedures can be grouped into 1) methods designed to effect the separation between residual and non residual metals only and 2) more elaborate methods making use of sequential extractions. The former method normally involve a single extraction and offer a better contrast between anomalous and back ground samples than does the determination of the total metal concentration. Despite their rapidity and relative simplicity these techniques suffer from the difficulty of finding a single reagent effective in dissolving quantitatively the non residual forms of metal without attacking the detrital forms. The use of sequential extraction although more time consuming, furnishes detailed information about the origin, mode of occurrence, biological and physicochemical availability, mobilization, and transport of trace metals. Two major experimental problems with sequential procedures have been recognized: non selectivity of extractants, and trace elements redistribution among phases during extraction [39]. Generally it is difficult to associate a given extractant reagent with a particular physicochemical phase. Most validation studies have focused on selectivity and extraction completeness rather than redistribution and predominantly from the stand point of major species rather than trace elements [40]-[42]. The partitioning obtained by such procedures is, however, influenced by factors such as the choice of reagents used for the various extractions and the extraction sequence, and the time of extraction [40] [43]-[45]. In this work, based on the research of the distribution of trace element in coal, Tessier sequential extraction method and acid rain simulation method were used to evaluation of speciation of some trace elements in particles released from coal combustion.

\section{Experimental}

\subsection{Instrumentation and Reagents}

\subsubsection{GFAAS}

3200 Atomic absorption spectrometry (Shanghai Analytical Instrumentation Factory) equipped with graphite furnace and with deuterium back ground correction was used throughout the work. The instrument was cooled during heating by water and argon was used as a carrier gas. Lead hollow cathode lamp operated at $6 \mathrm{~mA}$ with wave length $2833 \mathrm{~nm}$ was used. The instrument connected with desk automatic balancing recorder (Dahua instrument factory Shanghai China). The optimized parameters were $0.12 \mathrm{~A} ; 30 \mathrm{~S}$ (dry temperature), $0.47 \mathrm{~A}$; $30 \mathrm{~S}$ (ash temp.) and $2.1 \mathrm{~A} ; 4 \mathrm{~S}$ (atomization temp.). As shown in Table 1. All reagents used in this work were of analytical-reagent grade, and doubly de-ionized water was used throughout. The stock standard solution, 1000 $\mathrm{mg} \cdot \mathrm{L}^{-1}$ for lead, was prepared from pure lead metal dissolved in $1: 1 \mathrm{HNO}_{3}$ and completed to the volume with water. 
Table 1. Parameters for GFAAS determination of lead.

\begin{tabular}{ccccccccc}
\hline \multirow{2}{*}{$\begin{array}{c}\text { Wave } \\
\text { length }\end{array}$} & $\begin{array}{c}\text { Current for } \\
\mathrm{HCl}\end{array}$ & \multicolumn{2}{c}{ Drying temp. } & \multicolumn{2}{c}{ Ashing temp. } & \multicolumn{2}{c}{ Atomization temp. } \\
\cline { 3 - 7 } & & Current & Time & Current & Time & Current & Time \\
2833 & $6 \mathrm{~mA}$ & $0.12 \mathrm{~A}$ & $30 \mathrm{~S}$ & $0.47 \mathrm{~A}$ & $30 \mathrm{~S}$ & $2.1 \mathrm{~A}$ & $4 \mathrm{~S}$ \\
\hline
\end{tabular}

\subsubsection{HGAAS-FIA}

3200 Atomic absorption spectrometry (Shanghai Analytical Instrument Factory) with arsenic hollow cathode lamp operated at $10 \mathrm{~mA}$ with wave length $1937 \mathrm{~nm}$ was used throughout the work with increment 7 . The instrument connected with desk automatic balancing recorder (Dahua Instrument Factory Shanghai China), peristaltic pump (Gilson Minipuls 2), injection valve, reaction cell, gas-liquid separator, air/ $\mathrm{C}_{2} \mathrm{H}_{2}$ flame heated quartz cell. All reagents were of analytical reagent grade, and doubly de-ionized water was used throughout. The stock standard solution, $1000 \mathrm{mg} \cdot \mathrm{L}^{-1}$ for $\mathrm{As}(\mathrm{III})$ was prepared from sodium arsenite $\left(\mathrm{NaAsO}_{2}\right)$ with water. The stock standard solution, $1000 \mathrm{mg} \cdot \mathrm{L}^{-1}$ for $\mathrm{As}(\mathrm{V})$ was prepared from sodium arsenate $\left(\mathrm{Na}_{3} \mathrm{AsO}_{4} \cdot 12 \mathrm{H}_{2} \mathrm{O}\right)$ with water. L-cysteine stock solution was prepared by dissolving $5 \mathrm{~g}$ of L-cysteine $\left(\mathrm{C}_{3} \mathrm{H}_{7} \mathrm{NO}_{2} \mathrm{~S}\right)$ in $100 \mathrm{ml}$ of $0.5 \mathrm{~mol} / \mathrm{L} \mathrm{HCl}$, for the prereduction of arsenic (V), $2 \mathrm{ml}$ of L-cysteine stock solution were added per $10 \mathrm{ml}$.

\subsubsection{ICP-AES}

A spectro ICP-AES (Made in W. Germany 1991) controlled by an IBM ps/2 computer, was used throughout this work. PH meter and centrifuge were also used. Pump speed $2 \mathrm{ml} / \mathrm{min}$ and tube length $110 \mathrm{~cm}$. The power of emission $1200 \mathrm{~W}$.

All reagents were of analytical-reagent grade, and doubly de-ionized water was used throughout. The stock standard solutions used were as follows: GBW (E) $08005100 \mu \mathrm{g} / \mathrm{ml}$ for Cd, WB0113 $100 \mu \mathrm{g} / \mathrm{ml}$ for Co, GSBG62023-90 $1000 \mu \mathrm{g} / \mathrm{ml}$ for Cu, GBW (E) $100 \mu \mathrm{g} / \mathrm{ml}$ for Cr, and GBW (E) $080007100 \mu \mathrm{g} / \mathrm{ml}$ for Ni.

$1.0 \mathrm{ml}$ was taken from each stock solution of the elements $\mathrm{Cd}, \mathrm{Co}, \mathrm{Cr}$, and $\mathrm{Ni}$, and $0.1 \mathrm{ml}$ from the stock solution of $\mathrm{Cu}$, all they were mixed in $100 \mathrm{ml}$ volumetric flask and diluted to the mark with distilled water.

\subsection{Methods}

\subsubsection{GFAAS}

The SRM 8322 after dried $\left(110^{\circ} \mathrm{C}\right)$ for $1 \mathrm{~h}, 0.999 \mathrm{~g}$ was weighed accurately, burned to $650^{\circ} \mathrm{C}$ for $1 \mathrm{~h}$ and digested with the following acids: $\mathrm{HNO}_{3}(3 \mathrm{ml}), \mathrm{HF}(5 \mathrm{ml}), \mathrm{HClO}_{4}(5 \mathrm{ml})$ after each addition the solution evaporated to near dryness, finally $\mathrm{HCl}(10 \mathrm{ml})$ was added and heated until the appearance of a bubble and transferred to $100 \mathrm{ml}$ volumetric flask and completed to the mark with water. A series of standard solutions 20 - 80 ppb were prepared from the stock standard solution. $20 \mu \mathrm{l}$ from standard solution and SRM was injected in the GF for the determination of lead. The calibration curve for the standard solution of $\mathrm{Pb}$ was shown in Figure 1. In this work a direct injection of a sample solution into the graphite furnace without matrix separation and preconcentration, we got a good result, after using the Deuterium lamp for back ground correction. The lead in the standard reference material SRM 8322 (fly ash from combustion of pulverized coal, Research Centre of Environmental Science of China) was determined. The average of five determinations was $33.5 \mu \mathrm{g} / \mathrm{g}$. The certificate value of SRM 8322 is $33.8 \pm 4.4 \mu \mathrm{g} / \mathrm{g}$. The data was analyzed by the soft ware Basica.

\subsubsection{HGAAS-FIA}

The SRM after dried to $110^{\circ} \mathrm{C}$ for $1 \mathrm{~h}, 1.0 \mathrm{~g}$ was weighed accurately and burned to $650^{\circ} \mathrm{C}$ for $1 \mathrm{~h}$, then dissolved in an acid mixture as follows: $\mathrm{HNO}_{3}(3 \mathrm{ml})$, $\mathrm{HF}(5 \mathrm{ml}), \mathrm{HCLO}_{4}(5 \mathrm{ml})$ after each addition of the acid the solution evaporated to near dryness and finally $10 \mathrm{ml}$ of $\mathrm{HCl}$ was added and heated until the solution was bubbled. The solution transferred to $100 \mathrm{ml}$ volumetric flask and completed to the mark with water and analyzed by FIHGAAS for determination of As in SRM.

\subsubsection{Sampling}

The samples studied were from Qingshan Thermoelectric Plant, there are two types of samples according to combustion condition $170 \mathrm{t} / \mathrm{h}$, and $220 \mathrm{t} / \mathrm{h}$.

Sample $170 \mathrm{t} / \mathrm{h}$ was burned in an oxidizing condition, temp. $1261^{\circ} \mathrm{C}, \mathrm{CO}_{2} 13.12 \%, \mathrm{O}_{2} 6.15 \%, \mathrm{CO} 0.014 \%$. 


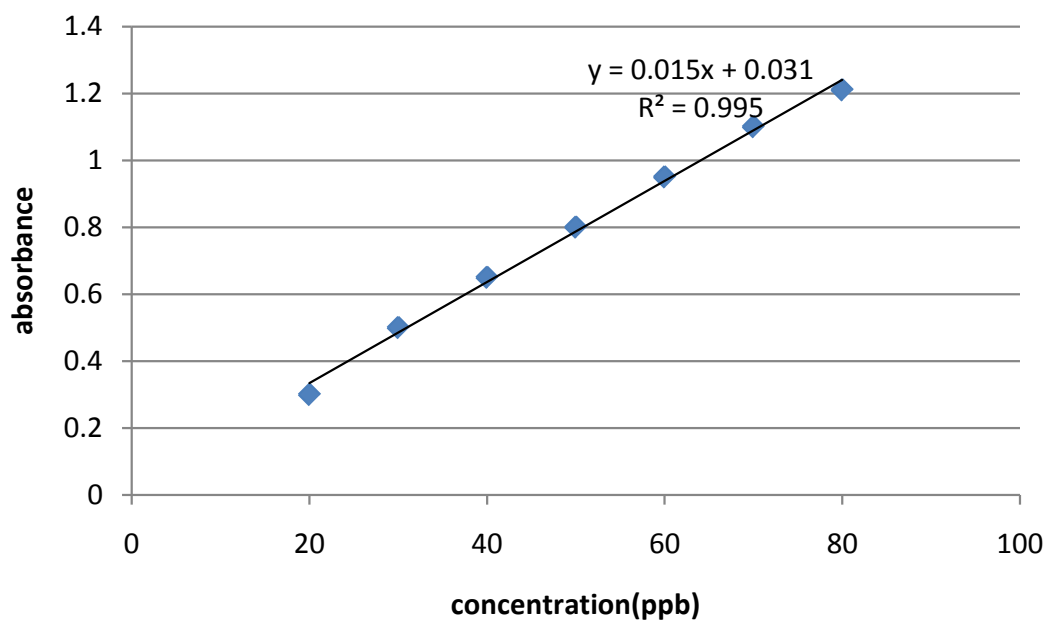

Figure 1. Calibration curve for standard solution of $\mathrm{Pb}$.

Sample $220 \mathrm{t} / \mathrm{h}$ was burned in reducing condition, temp. $1323^{\circ} \mathrm{C}, \mathrm{CO}_{2} 17.76 \%, \mathrm{O}_{2} 1.29 \%, \mathrm{CO} 0.12 \%$.

Two different particles of fly ash were sampled for each condition of combustion. The average size of the fly ash was $1.7 \mu \mathrm{m}$ and $4.8 \mu \mathrm{m}$ respectively for the two different conditions.

\subsubsection{Sample Preparation}

The samples were dried at $106^{\circ} \mathrm{C}$ for one hour, and then one gram from each sample was weighed. The sample can be partitioned into specific fractions which can be extracted selectively by using appropriate reagents. For total trace metal analysis, the sample was also dried at $106^{\circ} \mathrm{C}$ for one hour, and $1.0 \mathrm{~g}$ was weighed accurately and then burned at $650^{\circ} \mathrm{C}$ for one hour. The sample was digested with the following acids: $3 \mathrm{ml} \mathrm{HNO}_{3}, 5 \mathrm{ml} \mathrm{HF}$, and $5 \mathrm{ml} \mathrm{HCLO}_{4}$ after addition of the acids the solution was evaporated to near dryness and finally $10 \mathrm{ml}$ of $\mathrm{HCl}$ were added until the appearance of bubbles and at last the sample was diluted to $50 \mathrm{ml}$ and then analyzed by ICP-AES.

\subsubsection{Sequential Extraction}

There are five fractions chosen which are likely to be affected by environmental conditions.

1) Exchangeable

The coal was extracted at room temperature for $1 \mathrm{~h}$ with $8 \mathrm{ml}$ of magnesium chloride solution $\left(1 \mathrm{M} \mathrm{MgCl}_{2}\right.$, $\mathrm{pH}$ 7.0).

2) Bound to carbonate

The residue from 1) was leached at room temperature for $5 \mathrm{~h}$ with $8 \mathrm{ml}$ of $1 \mathrm{M} \mathrm{NaOAC}$ adjusted to $\mathrm{pH} 5.0$ with acetic acid. The extraction was maintained with continuous agitation.

3) Bound to Fe-Mn oxide

The residue from 2) was extracted with $20.0 \mathrm{ml}$ of $0.3 \mathrm{M} \mathrm{Na}_{2} \mathrm{~S}_{2} \mathrm{O}_{3}+0.175 \mathrm{M} \mathrm{Na}$-citrate $+0.025 \mathrm{M}$ H-citrate. The experiment was performed at $96^{\circ} \mathrm{C} \pm 3^{\circ} \mathrm{C}$ with occasional agitation for $6 \mathrm{~h}$.

4) Bound to organic matter

To the residue from 3) $3 \mathrm{ml}$ of $0.02 \mathrm{M} \mathrm{HNO}_{3}$ and $5 \mathrm{ml}$ of $30 \% \mathrm{H}_{2} \mathrm{O}_{2}$ adjusted to $\mathrm{pH} 2.0$ with $\mathrm{HNO}_{3}$ were added and the mixture was heated to $85^{\circ} \mathrm{C} \pm 2^{\circ} \mathrm{C}$ for $2 \mathrm{~h}$ with occasional agitation. A second $3.0 \mathrm{ml}$ aliquot of $30 \%$ $\mathrm{H}_{2} \mathrm{O}_{2}\left(\mathrm{pH}=2\right.$ with $\mathrm{HNO}_{3}$ ) was then added and the sample was heated again to $85^{\circ} \mathrm{C} \pm 2^{\circ} \mathrm{C}$ for $3 \mathrm{~h}$ with intermittent agitation. After cooling, $5.0 \mathrm{ml}$ of $3.2 \mathrm{M} \mathrm{NH}_{4} \mathrm{OAC}$ in $20 \%(\mathrm{v} / \mathrm{v}) \mathrm{HNO}_{3}$ was added and the sample was diluted to $20.0 \mathrm{ml}$ and agitated continuously for $30 \mathrm{~min}$. the addition of $\mathrm{NH}_{4} \mathrm{OAC}$ is designed to prevent adsorption of extracted metals onto the oxidized coal.

5) Residual

For residual trace metal analysis, the solid was digested with a 10:1 mixture of hydrofluoric and perchloric acids. The residue was first digested with a solution of concentrated $\mathrm{HCLO}_{4}(2 \mathrm{ml})$ and $\mathrm{HF}(20)$ to near dryness; subsequently a second addition of $\mathrm{HCLO}_{4}(1 \mathrm{ml})$ and $\mathrm{HF}(10 \mathrm{ml})$ was made and again the mixture was evaporated to near dryness. Finally, $\mathrm{HCLO}_{4}(1 \mathrm{ml})$ alone was added and the sample was evaporated until the appear- 
ance of white fumes. The residue was dissolved in $12 \mathrm{~N}$ HCL.

\subsubsection{Acid Rain Simulation}

$3.0 \mathrm{~g}$ of $170 \mathrm{t} / \mathrm{h}$ sample of fly ash $(1.7 \mu \mathrm{m})$ was taken. $0.0173 \mathrm{~g} \mathrm{CaCl}, 0.0111 \mathrm{~g} \mathrm{MgSO}_{4}$ and $0.0083 \mathrm{~g} \mathrm{NH}_{4} \mathrm{NO}_{3}$ were dissolved in $1 \mathrm{~L}$ volumetric flask and diluted to the mark. $300 \mathrm{ml}$ was taken from the volumetric flask and divided into 5 flasks, then the $\mathrm{pH}$ in each flask adjusted with $\mathrm{H}_{2} \mathrm{SO}_{4}$, the $\mathrm{pH}$ is as follows: 2, 2.5, 3.5, 4.5, and 5.6.

10 samples were arranged, 5 for one hour and the other 5 for two hours.

$30 \mathrm{ml}$ was taken from each flask and added to the first 5 samples $(1 \mathrm{~h})$, again $30 \mathrm{ml}$ from each flask was taken and added to the other 5 samples $(2 \mathrm{~h})$. The extracted solution was analyzed by ICP-AES for trace elements.

\subsubsection{Distribution of Trace Elements in Coal}

Approximately $50 \mathrm{~g}$ of coal was weighed and transferred to $1000 \mathrm{ml}$ measuring cylinder, completed to the mark with distilled water, and allowed to settle with occasional stirring. After 3 hours, 3 fractions were sampled respectively. Again $150 \mathrm{ml}$ was extracted at 6 hours, and $150 \mathrm{ml}$ at 24 hours, and finally the last fraction was taken. Each fraction was filtered and the filterates were dried at $110^{\circ} \mathrm{C}$ for one hour. $0.5 \mathrm{~g}$ was weighed accurately from each fraction, burned at $650^{\circ} \mathrm{C}$ for one hour and finally digested with the acid mixture as follows: $\mathrm{HNO}_{3}(3 \mathrm{ml})$, $\mathrm{HF}(5 \mathrm{ml}), \mathrm{HCLO}_{4}(5 \mathrm{ml})$ after each addition of the acid the solution evaporated to near dryness, at last $\mathrm{HCl}(10$ $\mathrm{ml}$ ) was added and the solution heated until it bubbled. The solutions were transferred to $50 \mathrm{ml}$ volumetric flask completed to the mark with water. The samples were analyzed by ICP-AES for trace elements. For the comparison of trace elements concentration in coal before and after extraction with dimethyl benzene, $1.0 \mathrm{~g}$ was weighed accurately after to $110^{\circ} \mathrm{C}$ for one hour, $20 \mathrm{ml}$ of dimethyl benzene were added for 24 hours with occasional stirring then the solution was filtered and the filterate burned at $650^{\circ} \mathrm{C}$ for 1 hour. Another $1.0 \mathrm{~g}$ was weighed accurately after dried at $110^{\circ} \mathrm{C}$ for 1 hour and at $650^{\circ} \mathrm{C}$ for 1 hour. The two samples were digested with the acid mixtures as the above procedures, transferred to $50 \mathrm{ml}$ volumetric flask, completed to the mark with distilled water and analyzed by ICP-AES.

\subsection{Optimization of Experimental Conditions}

\subsubsection{Optimization of Acid Concentration}

To find the best condition for the determination of As(III) without using L-cysteine as a prereductant, different acid concentrations in the range $0.1-6 \mathrm{~mol} / \mathrm{L}$ were tested. It is found $2 \mathrm{~mol} / \mathrm{L} \mathrm{HCl}$ for the carrier was the best condition, higher acid concentrations had little or no effect on arsenic absorbance. When using L-cysteine as a prereductant $1 \mathrm{~mol} / \mathrm{L} \mathrm{HCl}$ for the carrier was the optimum.

\subsubsection{Optimization of $\mathrm{NaBH}_{4}$ Concentration}

To determine the optimum sodium tetrahydroborate concentration, different concentrations in the range $0.1 \%$ $6 \%(\mathrm{w} / \mathrm{v})$ were tested. It is found above $4 \%$ concentration had very slightly effect. A concentration of $4 \%(\mathrm{w} / \mathrm{v})$ was chosen for further work. $4.0 \mathrm{~g}$ of $\mathrm{NaBH}_{4}$ dissolved in $100 \mathrm{ml}$ of water.

\subsubsection{Influence of Pumping Speed}

A pump speed in the range 200 - $900 \mathrm{rev} / \mathrm{h}$ was tested. The signal increased and became more nearly perfectly shaped with increasing pumping speed. A pumping speed of $800 \mathrm{rev} / \mathrm{h}$ (sample $3.1 \mathrm{ml} / \mathrm{min}, \mathrm{NaBH}_{4} 1.3 \mathrm{ml} / \mathrm{min}$ and carrier $2.5 \mathrm{ml} / \mathrm{min}$ ) was chosen for further work.

\section{Results}

From the agreement of the results of lead and arsenic with the certified value, the methods can be used for the determination of lead and arsenic in coal. The results of speciation of trace elements by Tessier sequential extraction for fly ash under two different conditions of combustion are shown in Table 2, Table 3, and Figures 2-7.

The results of acid rain simulation are shown in Table 4.

The results of the distribution of trace elements in coal are as in Table 5 and Table 6.

In order to evaluate the reliability of speciation method of Tessier sequential extraction, the total amounts of trace elements in different samples of fly ash were determined. The results are shown in Table 7. 
Table 2. Analyzing $1.0 \mathrm{~g}$ of $170 \mathrm{t} / \mathrm{h}$ sample $(1.7 \mu \mathrm{m})$ using sequential extraction, the concentration in ppm.

\begin{tabular}{ccccccc}
\hline \multirow{2}{*}{ Trace elements } & \multicolumn{5}{c}{ Concentration of the elements in the fractions } & Total concentration \\
\cline { 2 - 5 } & 1 & 2 & 3 & 4 & 5 & 3.1 \\
$\mathrm{Cd}$ & 0.00 & 0.0032 & 0.23 & 0.075 & 2.8 & 27.3 \\
$\mathrm{Co}$ & 0.019 & 0.32 & 1.1 & 1.01 & 24.9 & 74.3 \\
$\mathrm{Cu}$ & 0.00 & 1.6 & 7.1 & 5.1 & 60.5 & 75.5 \\
$\mathrm{Cr}$ & 0.45 & 1.3 & 2.9 & 1.3 & 69.6 & 53.6 \\
$\mathrm{Ni}$ & 0.38 & 2.0 & 5.0 & 3.5 & 49.7 & \\
\hline
\end{tabular}

Table 3. Analyzing $1.0 \mathrm{~g}$ of $220 \mathrm{t} / \mathrm{h}$ sample $(4.8 \mu \mathrm{m})$.

\begin{tabular}{|c|c|c|c|c|c|c|}
\hline \multirow{2}{*}{ Trace elements } & \multicolumn{5}{|c|}{ Concentration of the elements in the fractions } & \multirow{2}{*}{ Total concentration } \\
\hline & 1 & 2 & 3 & 4 & 5 & \\
\hline $\mathrm{Cd}$ & 0.00 & 0.047 & 0.27 & 0.066 & 3.6 & 4.007 \\
\hline Co & 0.024 & 0.24 & 0.83 & 0.79 & 21.5 & 23.4 \\
\hline $\mathrm{Cu}$ & 0.66 & 1.43 & 1.3 & 2.7 & 49.0 & 55.1 \\
\hline $\mathrm{Cr}$ & 1.6 & 1.03 & 2.4 & 1.8 & 69.4 & 76.1 \\
\hline $\mathrm{Ni}$ & 0.44 & 2.2 & 3.1 & 3.06 & 39.1 & 47.8 \\
\hline
\end{tabular}

Table 4. The concentration of trace elements in ppm at different $\mathrm{pH}$.

\begin{tabular}{cccccccccc}
\hline & \multicolumn{9}{c}{ For one hour } \\
\cline { 2 - 10 }$y$ & $\mathrm{Co}$ & $\mathrm{Cu}$ & $\mathrm{Cr}$ & $\mathrm{Ni}$ & $\mathrm{Co}$ & $\mathrm{Cu}$ & $\mathrm{Cr}$ & $\mathrm{Ni}$ \\
\hline 5.6 & 0.00 & 0.00 & 0.031 & 0.016 & 0.00 & 0.00 & 0.048 & 0.02 \\
4.5 & 0.00 & 0.00 & 0.028 & 0.014 & 0.00 & 0.00 & 0.063 & 0.034 \\
3.5 & 0.00 & 0.00 & 0.035 & 0.00 & 0.0008 & 0.00 & 0.06 & 0.021 \\
2.5 & 0.0021 & 0.032 & 0.039 & 0.029 & 0.0048 & 0.022 & 0.045 & 0.045 \\
2 & 0.017 & 0.14 & 0.101 & 0.12 & 0.0 .014 & 0.13 & 0.1 & 0.14 \\
\hline
\end{tabular}

Table 5. Content of trace elements in coal extracted by water with different time $(\mu \mathrm{g} / \mathrm{g})$.

\begin{tabular}{|c|c|c|c|c|c|c|c|}
\hline \multirow{2}{*}{\multicolumn{2}{|c|}{$\begin{array}{c}\text { Time for separation } \\
\text { No. of fractions }\end{array}$}} & \multicolumn{3}{|c|}{ Extraction for $3 \mathrm{~h}$} & \multirow{2}{*}{$\begin{array}{c}6 \mathrm{~h} \\
4\end{array}$} & \multirow{2}{*}{$\begin{array}{c}24 \mathrm{~h} \\
5\end{array}$} & \multirow{2}{*}{$\begin{array}{c}\text { Last fraction } \\
6\end{array}$} \\
\hline & & 1 & 2 & 3 & & & \\
\hline \multirow{7}{*}{ Elements } & As & $6.5 \pm 0.13$ & $1.4 \pm 0.5$ & $2.4 \pm 0.72$ & $1.1 \pm 0.3$ & $0.54 \pm 0.15$ & $0.88 \pm 0.35$ \\
\hline & $\mathrm{Be}$ & $2.7 \pm 0.52$ & $0.88 \pm 0.21$ & $1.4 \pm 0.53$ & $0.77 \pm 0.25$ & 0.00 & 0.00 \\
\hline & $\mathrm{Cd}$ & 0.28 & 0.2 & 0.24 & 0.2 & $0.18 \pm 0.05$ & 0.16 \\
\hline & $\mathrm{Pb}$ & 21.6 & 17.7 & 17.5 & 10.7 & 18.3 & 13.5 \\
\hline & Co & $11.2 \pm 0.15$ & $16.3 \pm 0.73$ & $15.0 \pm 1.1$ & $13.7 \pm 0.49$ & $11.9 \pm 2.9$ & $11.6 \pm 0.74$ \\
\hline & $\mathrm{Cu}$ & 106.1 & 96.8 & 67.1 & $58.0 \pm 2.0$ & $42.8 \pm 0.05$ & $61.2 \pm 1.9$ \\
\hline & $\mathrm{Cr}$ & $61.3 \pm 0.045$ & $85.3 \pm 0.65$ & 47.9 & $54.0 \pm 0.78$ & $71.0 \pm 0.16$ & $36.0 \pm 0.63$ \\
\hline
\end{tabular}

Table 6. Content of trace elements in coal before and after extraction with dimethyl benzene $(\mu \mathrm{g} / \mathrm{g})$.

\begin{tabular}{cccc}
\hline Elements & Original coal & After extraction with dimethyl benzene & Difference \\
\hline $\mathrm{As}$ & $0.17 \pm 0.05$ & 0.00 & Yes \\
$\mathrm{Be}$ & $2.1 \pm 0.084$ & $1.6 \pm 0.1$ & Yes \\
$\mathrm{Cd}$ & 0.13 & 0.14 & 5.7 \\
$\mathrm{~Pb}$ & 5.6 & $9.8 \pm 0.0075$ & No \\
$\mathrm{Co}$ & $9.8 \pm 0.1$ & 59.9 & No \\
$\mathrm{Cu}$ & 60.4 & 12.7 & No \\
$\mathrm{Cr}$ & $22.0 \pm 0.33$ & $12.1 \pm 0.41$ & Yes \\
$\mathrm{Ni}$ & 11.1 & & No \\
\hline
\end{tabular}


Table 7. Analyzing 1.0 g sample for total trace elements concentration, the concentration in ppm.

\begin{tabular}{cccccc}
\hline \multirow{2}{*}{ Sample } & \multicolumn{4}{c}{ Elements } \\
\cline { 2 - 6 } & Cd & Co & Cu & Cr & Ni \\
\hline $170 \mathrm{t} / \mathrm{h}(1.7 \mu \mathrm{m})$ & 4.05 & 27.7 & 92.0 & 53.7 & 57.3 \\
$220 \mathrm{t} / \mathrm{h}(4.8 \mu \mathrm{m})$ & 4.2 & 20.9 & 63.6 & 48.7 & 46.8 \\
\hline
\end{tabular}

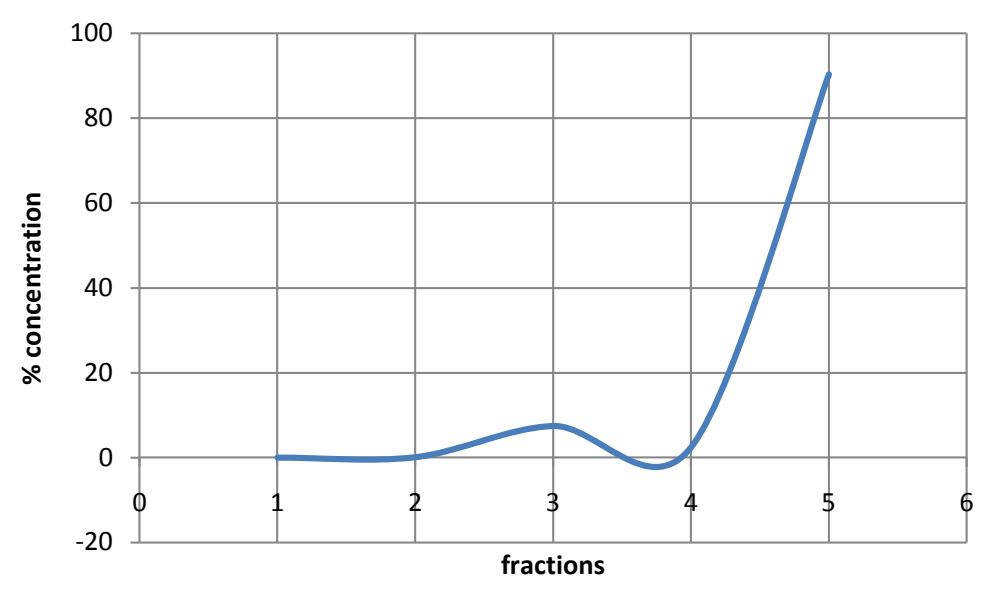

Figure 2. Cd in $1.0 \mathrm{~g}$ of $170 \mathrm{t} / \mathrm{h}$ sample $(1.7 \mu \mathrm{m})$ using sequential extraction.

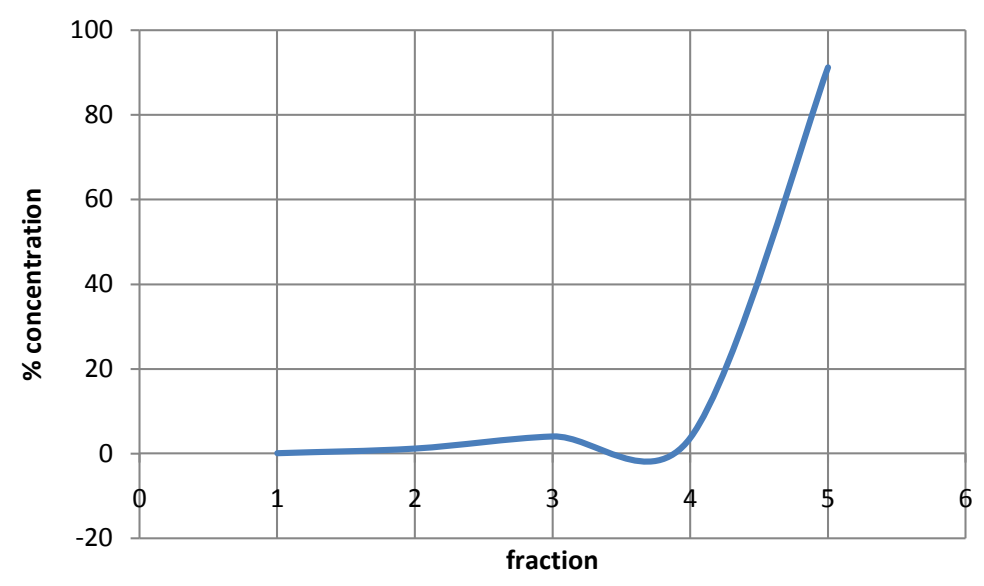

Figure 3. Co in $1.0 \mathrm{~g}$ of $170 \mathrm{t} / \mathrm{h}$ sample $(1.7 \mu \mathrm{m})$ using sequential extraction.

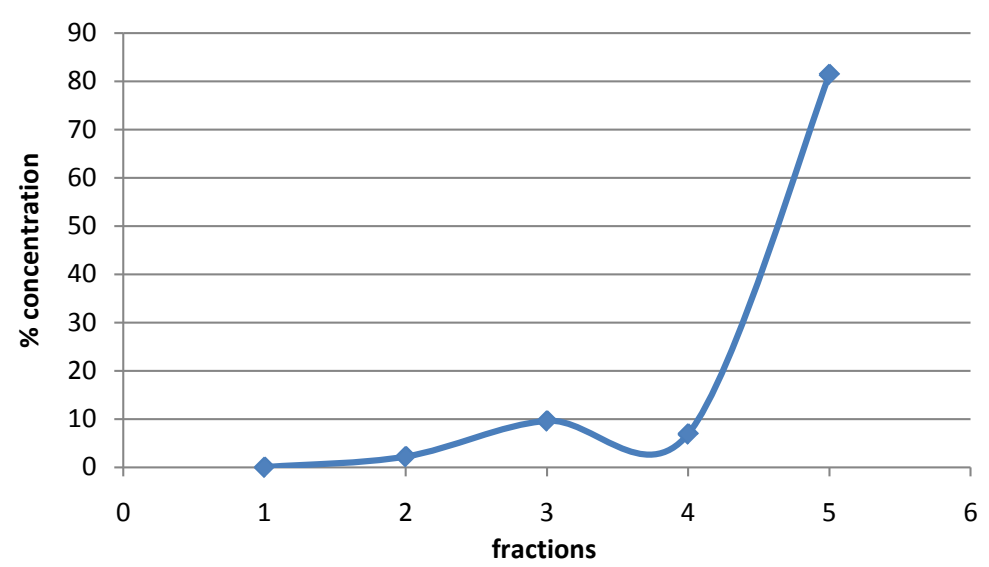

Figure 4. $\mathrm{Cu}$ in $1.0 \mathrm{~g}$ of $170 \mathrm{t} / \mathrm{h}$ sample $(1.7 \mu \mathrm{m})$ using sequential extraction. 


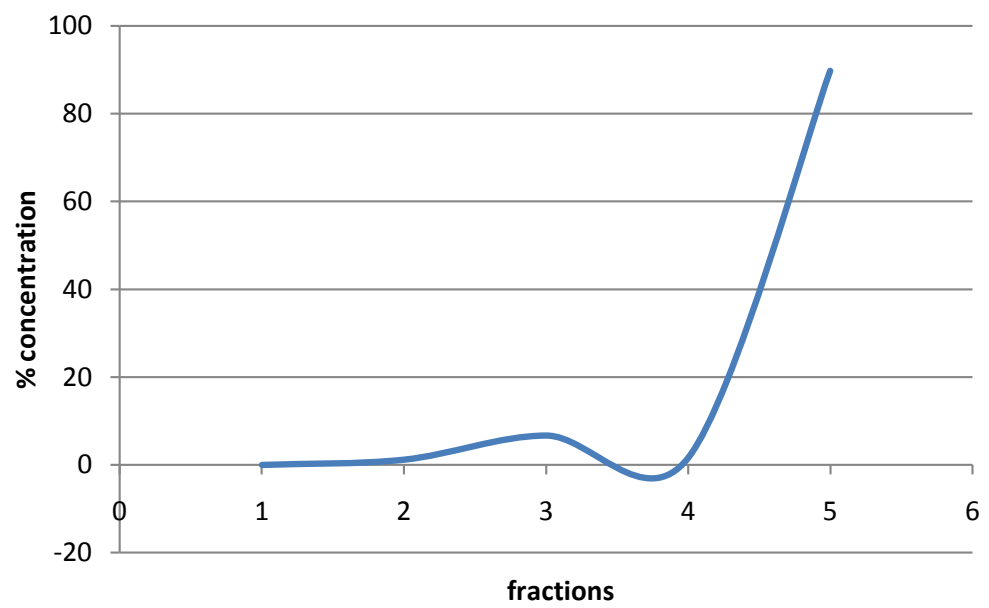

Figure 5. Cd in $1.0 \mathrm{~g}$ of $220 \mathrm{t} / \mathrm{h}$ sample $(4.8 \mu \mathrm{m})$ using sequential extraction.

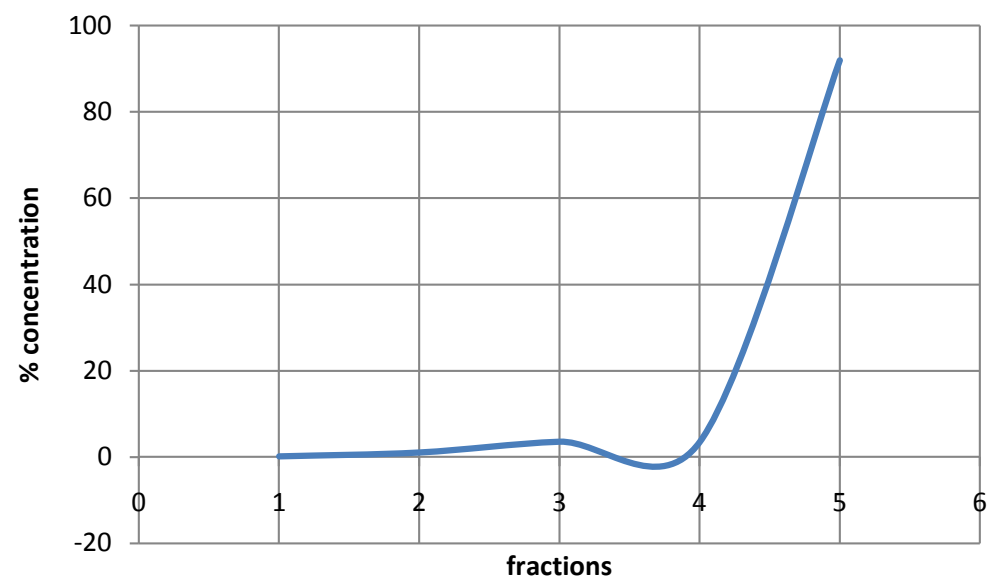

Figure 6. Co in $1.0 \mathrm{~g}$ of $220 \mathrm{t} / \mathrm{h}$ sample $(4.8 \mu \mathrm{m})$ using sequential extraction.

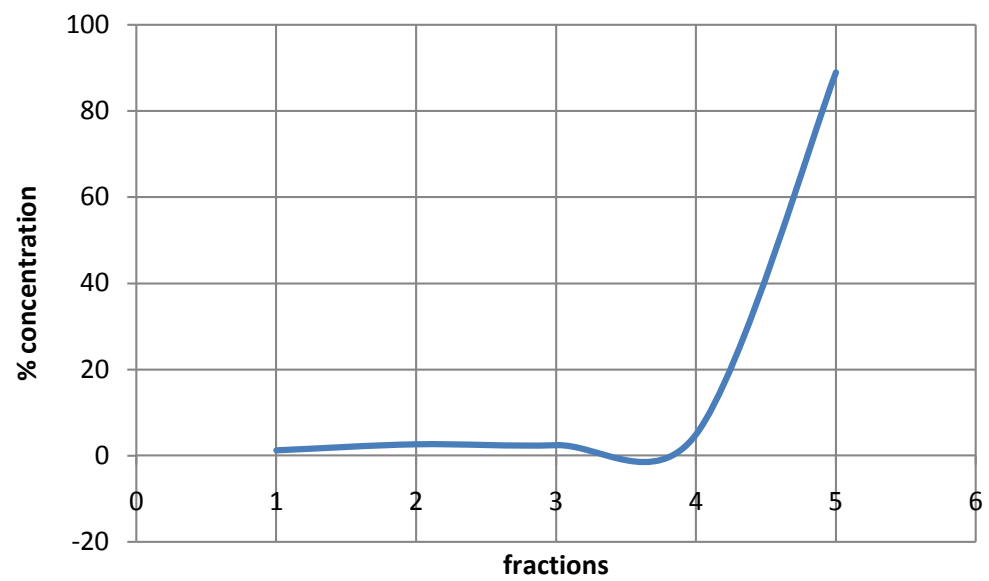

Figure 7. $\mathrm{Cu}$ in $1.0 \mathrm{~g}$ of $220 \mathrm{t} / \mathrm{h}$ sample $(4.8 \mu \mathrm{m})$ using sequential extraction.

\section{Discussion}

From the results of this work it appeared that the total concentration of trace elements in fly ash of $170 \mathrm{t} / \mathrm{h}(1.7$ $\mu \mathrm{m})$ were higher than of $220 \mathrm{t} / \mathrm{h}(4.8 \mu \mathrm{m})$. According to our previous research work the total concentration of trace elements in $220 \mathrm{t} / \mathrm{h}$ dreg samples were higher than the fly ash of the same condition $220 \mathrm{t} / \mathrm{h}(4.8 \mu \mathrm{m})$, but 
with the fly ash $170 \mathrm{t} / \mathrm{h}$ the increase and decrease is irregular. The results also shows the trace elements in the fine particles were easily to be extracted than in dreg samples. From these observations it is better to use higher temperature for combustion to decrease the air pollution. Only small parts of the total trace elements released into water when act with acid rain, release quantity increase with the decrease of $\mathrm{pH}$ of the acid rain, when $\mathrm{pH}<$ 2.5 release is significant high. The effect of the concentration of $\mathrm{MgCl}_{2}$ and $\mathrm{NaOAc}$ can be observed in acid rain extraction $\mathrm{pH} 4.5$ - 5.6 and the sequential extraction $\mathrm{pH} 7$ and $\mathrm{pH}$ 5. The extraction in sequential extraction is higher than in acid rain simulation. This shows that the release of trace elements from particles into water system not only depend on $\mathrm{pH}$ of leaching agent but also on the concentration of the salt in leaching agents. The sum of the five fractions equal the total determination. This shows the results of sequential extractions were reliable. The results of extraction at $2 \mathrm{~h}$ higher than $1 \mathrm{~h}$ (sometimes lower) can be explained by sorption-desorption on the surface of particles. The content of exchangeable part is very low because exchangeable species is ion species adsorbed on surface of particles, after combustion (high temp.) the trace elements is not the adsorbed species. The content of carbonate is also low during combustion, carbonate decompose, but some part of the metal oxide may react with $\mathrm{CO}_{2}$ to form carbonate, therefore there is small quantity of carbonate in fly ash. Because of the un-complete combustion of coal, there are small quantity of organic matter in the fly ash, so there are some organic associated trace elements in the fly ash. The results show that the organic associated part are higher than exchangeable and carbonate associated part. The trace elements in this parts may be release into water system under oxidation condition or biological effect. The content of Fe-Mn oxide associated trace elements in fly ash are similar to those in organic matter. This part is unstable under reduction conduction. Also according to our previous work, the stable residual part of trace elements of $\mathrm{Cd}, \mathrm{Co}, \mathrm{Ni}$ in dreg are higher than those in fly ash, this means that the unstable and substable species (exchangeable, carbonate, Fe-Mn oxide, and organic) in fly ash are higher than in dreg, that the fly ash is more important for heavy metals pollution of the environment. Generally with the increase of settlement time, the gravity increase. The smaller of gravity the more of organic substance. From Table 2 we can see the concentration of As and Be are decreased with the increase of gravity. It showed that these two elements associated mainly with organic substance. The results of the extraction by dimethyl benzene in Table 3 showed that after extraction with dimethyl benzene the concentration of As, Be and Cr showed a significant difference with the original coal. While other elements showed no difference. It means trace elements As, Be and $\mathrm{Cr}$ are generally associated with organic substance, while other elements associated with inorganic matter in coal.

\section{Conclusion}

Fly ash is one factor of air pollution. In this work lead had been determined by GFAAS, the method is simple and can be used for the determination of lead in coal fly ash. The arsenic determined by HGAAS-FIA method can be used for further determination of arsenic in coal fly ash. Different species of trace elements generally have different toxicity and bioavailability, so speciation of trace elements is interested in the field of environmental and life science. In particles of coal fly ash, some of the trace elements are mainly associated with organic matter, and some are mainly associated with minerals matter. The trace elements may exist in different forms in fly ash. As the temperature of combustion increase the content of trace elements in fly ash decrease. The release quantity of trace elements increased with the decrease of $\mathrm{pH}$. The residual is the most stable part. The speciation of trace elements in different size of coal fly ash is closely related to the circumstance of coal combustion, so the control of the condition of combustion e.g. temperature can decrease the air pollution of trace heavy metals.

\section{References}

[1] Raeva, A.A., Klykov, O.V., Kozliak, E.I., Pieerce, D.T. and Seames, W.S. (2011) In Situ Evaluation of Inorganic Matrix Effects on the Partitioning of Three Trace Elements (As, Sb, Se) at the Outset of Coal Combustion. Energy and Fuels, 25, 4290-4298. http://dx.doi.org/10.1021/ef200879j

[2] Willett, J.C., Finkelman, R.B., Mrocz Kowski, S.J., Palmer, C.A. and Koller, A. (2000) Semi-Quantitative Determination of the Modes of Occurrence of Elements in Coal: Results from an International Round Robin Project. Final Report, U.S. Geological Survey, Reston, 45 p.

[3] Davison, R.L., Natusch, D.F.S., Wallace, J.R. and Evans, C.A. (1974) Trace Elements in Fly Ash. Dependence of Concentration on Particle Size. Environmental Science and Technology, 8, 1107-1113. http://dx.doi.org/10.1021/es60098a003 
[4] Dale, L.S. and Chapman, J.F. (1999) IEA Collaborative Project on the Modes of Occurrence of Trace Elements in Coal (Phase 1). Final Report, Lucas Heights, NSW, Australia, Commonwealth Scientific and Industrial Research Organization, Division of Energy Technology, 18 p.

[5] Nelson, P.F. (2007) Trace Metal Emission in Fine Particles from Coal Combustion. Energy and Fuels, 21, 477-484. http://dx.doi.org/10.1021/ef060405q

[6] Chen, H.H., Laskin, A., Baltrusaitis, J., Groski, C.A., Scherer, M.M. and Grassian, V.H. (2012) Coal Fly Ash as a Source of Iron in Atmospheric Dust. Environmental Science and Technology, 46, 2112-2120. http://dx.doi.org/10.1021/es204102f

[7] Slavin, W., Manning, D.C. and Camrick, G.R. (1981) Atomic Spectroscopy, 2, 137.

[8] Weiz, B., et al. (1992) Time-Based and Volume-Based Sampling for Flow-Injection On-Line Sorbent Extraction Graphite Furnace Atomic Absorption Spectrometry. Analytica Chimica Acta, 261, 477-487. http://dx.doi.org/10.1016/0003-2670(92)80229-Z

[9] Fang, Z. and Weiz, B.J. (1989) High Efficiency Low Sample Consumption On-Line Ion-Exchange Pre-Concentration System for Flow Injection Flame Atomic Absorption Spectrometry. Journal of Analytical Atomic Spectrometry, 4, 543546. http://dx.doi.org/10.1039/ja9890400543

[10] Ruzicka, J. and Arndal, A. (1989) Sorbent Extraction in Flow Injection Analysis and Its Application to Enhancement of Atomic Spectrometry. Analytica Chimica Acta, 216, 243-255. http://dx.doi.org/10.1016/S0003-2670(00)82011-5

[11] Fang, Z., Guo, T. and Weiz, B. (1991) Determination of Cadmium, Lead and Copper in Water Samples by Flame Atomic-Absorption Spectrometry with Preconcentration by Flow-Injection On-Line Sorbent Extraction. Talanta, 38, 613-619. http://dx.doi.org/10.1016/0039-9140(91)80144-O

[12] Malamas, F., Bengtsson, M. and Johansson, G. (1984) On-Line Trace Metal Enrichment and Matrix Isolation in Atomic Absorption Spectrometry by a Column Containing Immobilized 8-Quinolinol in a Flow-Injection System. Analytica Chimica Acta, 160, 1-10. http://dx.doi.org/10.1016/S0003-2670(00)84503-1

[13] Nakashima, S., Sturgeon, R.E., Willie, S.N. and Berman, S.S. (1988) Determination of Trace Metals in Seawater by Graphite Furnace Atomic Absorption Spectrometry with Preconcentration on Silica-Immobilized 8-Hydroxyquinoline in a Flow-System. Fresenius' Zeitschrift für Analytische Chemie, 330, 592-595. http://dx.doi.org/10.1007/BF00473773

[14] Fang, Z., Sperling, M. and Welz, B. (1990) Flow Injection On-Line Sorbent Extraction Pre-Concentration for Graphite Furnace Atomic Absorption Spectrometry. Journal of Analytical Atomic Spectrometry, 5, 639-646. http://dx.doi.org/10.1039/ja9900500639

[15] Schlemmer, G. and Grobenski, Z. (1990) Determination of Arsenic, Cadmium, Lead and Selenium in Highly Mineralized Waters by Graphite-Furnace Atomic-Absorption Spectrometry. Talanta, 37, 545-553. http://dx.doi.org/10.1016/0039-9140(90)80195-L

[16] Sanady, M.C. (1978) Hidrol, Kozl., 58, 193.

[17] Raje, N., Kayasth, S., Asari, T.P.S. and Gangadharan, S. (1994) Proconcentration of Trace Elements from High-Purity Thorium and Uranium on Chelex-100 and Determination by Graphite Furnace Atomic Absorption Spectrometry with Zeeman-Effect Background Correction. Analytica Chimica Acta, 290, 371-377. http://dx.doi.org/10.1016/0003-2670(94)80125-8

[18] Gupta, J.G.S. and Bouvier, J.L. (1995) Direct Determination of Traces of Ag, Cd, Pb, Bi, Cr, Mn, Co, Ni, Li, Be, Cu and Sb in Environmental Waters and Geological Materials by Simultaneous Multi-Element Graphite Furnace Atomic Absorption Spectrometry with Zeeman-Effect Background Correction. Talanta, 42, 269-281. http://dx.doi.org/10.1016/0039-9140(94)00256-R

[19] Minezewski, J., Ska, J.C. and Dybezynski, R. (1982) Separation and Preconcentration Methods in Inorganic Trace Analysis. Ellis Horwood, Chichester, 37.

[20] Mizuike, A. (1983) Enrichment Techniques for Inorganic Trace Analysis. Springer, Berlin, 56.

[21] Zolotov, Y.A. and Kuzmin, N.M. (1990) Preconcentration of Trace Elements. Elsevier, Amsterdam, 79.

[22] Hiraide, M., Chen, Z., Sugimoto, K. and Kawaaguchi, H. (1995) Coprecipitation with Tin(IV) Hydroxide Followed by Removal of Tin Carrier for the Determination of Trace Heavy Metals by Graphite-Furnace Atomic Absorption Spectrometry. Analytica Chimica Acta, 302, 103-107. http://dx.doi.org/10.1016/0003-2670(94)00427-N

[23] Hendrikse, P.W., Slikkerveer, F.J., Zaalberg, J. and Hautfenne, A. (1988) Determination of Copper, Iron and Nickel in Oils and Fats by Direct Graphite Furnace Atomic Absorption Spectrometry: Results of a Collaborative Study and the Standardised Method. Pure and Applied Chemistry, 60, 893-900. http://dx.doi.org/10.1351/pac198860060893

[24] van Dalen, G. and Galan, L.D. (1994) Direct Determination of Particulate Elements in Edible Oils and Fats Using an Ultrasonic Slurry Sampler with Graphite Furnace Atomic Absorption Spectrometry. Spectrochimica Acta Part B: Atomic Spectroscopy, 49, 1689-1693. http://dx.doi.org/10.1016/0584-8547(94)80140-1

[25] Howard, A.G. and Arab-Zavar, M.H. (1981) Determination of “Inorganic” Arsenic(III) and Arsenic(V), "Methylarse- 
nic" and "Dimethylarsenic" Species by Selective Hydride Evolution Atomic-Absorption Spectroscopy. Analyst (London), 106, 213-220. http://dx.doi.org/10.1039/an9810600213

[26] Ebdon, L., Wilkinson, J.R. and Jackson, K.W. (1982) A Simple and Sensitive Continuous Hydride Generation System for the Determination of Arsenic and Selenium by Atomic Absorption and Atomic Fluorescence Spectrometry. Analytica Chimica Acta, 136, 191-199. http://dx.doi.org/10.1016/S0003-2670(01)95378-4

[27] Subramanian, K.S. and Méranger, J.C. (1982) Rapid Hydride Evolution-Electrothermal Atomisation Atomic-Absorption Spectrophotometric Method for Determining Arsenic and Selenium in Human Kidney and Liver. Analyst (London), 107, 157-162. http://dx.doi.org/10.1039/an9820700157

[28] Ruzicka, J. and Hansen, E.H. (1981) Flow Injection Analysis. Wiley, New York.

[29] Tyson, J.F., Appiten, J.M.H. and Idris, A.B. (1983) Flow Injection Sample Introduction Methods for Atomic-Absorption Spectrometry. Analyst (London), 108, 153-158. http://dx.doi.org/10.1039/an9830800153

[30] Nakazawa, H., Takabatake, E., Hino, S. and Mtema, C.A. (1983) Simultaneous Determination of Sulfamonomethoxine, Dinitolmide, Ethopabate, Sulfadimethoxine, and Sulfaquinoxaline in Chicken Tissues by High Performance Liquid Chromatography. Bunseki Kagaku, 32, 179-183. http://dx.doi.org/10.2116/bunsekikagaku.32.3_179

[31] Zhou, N., Frech, W. and Lundberg, E. (1983) Rapid Determination of Lead, Bismuth, Antimony and Silver in Steels by Flame Atomic Absorption Spectrometry Combined with Flow Injection Analysis. Analytica Chimica Acta, 153, $23-31$. http://dx.doi.org/10.1016/S0003-2670(00)85484-7

[32] Olson, S., Pessenda, L.C., Růžička, J. and Hansen, E.H. (1983) Combination of Flow Injection Analysis with Flame Atomic-Absorption Spectrophotometry: Determination of Trace Amounts of Heavy Metals in Polluted Seawater. Analyst (London), 108, 905-917. http://dx.doi.org/10.1039/an9830800905

[33] Kamson, O.F. and Townshend, A. (1983) Ion-Exchange Removal of Some Interferences on the Determination of Calcium by Flow Injection Analysis and Atomic Absorption Spectrometry. Analytica Chimica Acta, 155, 253-257. http://dx.doi.org/10.1016/S0003-2670(00)85601-9

[34] Nord, L. and Karlberg, B. (1983) Sample Preconcentration by Continuous Flow Extraction with a Flow Injection Atomic Absorption Detection System. Analytica Chimica Acta, 145, 151-158. http://dx.doi.org/10.1016/0003-2670(83)80057-9

[35] Skeggs, L.T. (1957) An Automatic Method for Colorimetric Analyses. American Journal of Clinical Pathology, 28, 311.

[36] Manabu, Y., Yasuda, M. and Yuroku, Y. (1985) Analytical Chemistry, 57, 1382-1385.

[37] Hisatake, N. and Masahiko, I. (1984) Automated Determination of Arsenic and Selenium by Atomic Absorption Spectrometry with Hydride Generation. Analytical Chemistry, 56, 2059-2063. http://dx.doi.org/10.1021/ac00276a018

[38] Bernhard, W. and Šucmanová, M. (1993) L-Cysteine as a Reducing and Releasing Agent for the Determination of Antimony and Arsenic Using Flow Injection Hydride Generation Atomic Absorption Spectrometry-Part 2. Interference Studies and the Analysis of Copper and Steel. Analyst, 118, 1425-1432. http://dx.doi.org/10.1039/an9931801425

[39] Kheboian, C. and Bauer, C.F. (1987) Accuracy of Selective Extraction Procedures for Metal Speciation in Model Aquatic Sediments. Analytical Chemistry, 59, 1417-1423. http://dx.doi.org/10.1021/ac00137a010

[40] Tessier, A., Campbell, P.G.C. and Bisson, M. (1979) Sequential Extraction Procedure for the Speciation of Particulate Trace Metals. Analytical Chemistry, 51, 844-851. http://dx.doi.org/10.1021/ac50043a017

[41] Jouanneau, J.M., Latouche, C. and Pautrizel, F. (1983) Analyse critique des extractions sequentielles a travers l'etude de quelques constituants des residus d'attaque critical analysis of sequential extractions through the study of several attack constituent residues. Environmental Technology Letters, 4, 509-514. http://dx.doi.org/10.1080/09593338309384240

[42] Maher, W.A. (1984) Evaluation of a Sequential Extraction Scheme to Study Associations of Trace Elements in Estuarine and Oceanic Sediments. Bulletin of Environmental Contamination and Toxicology, 32, 339-344. http://dx.doi.org/10.1007/BF01607507

[43] Rendell, P.S., Batley, G.E. and Cameron, A.J. (1980) Adsorption as a Control of Metal Concentrations in Sediment Extracts. Environmental Science Technology, 14, 314-318. http://dx.doi.org/10.1021/es60163a002

[44] Rapin, F. and Forstner, U. (1983) Processing of the 4th International Conference on Heavy Metals in the Environment. CEP Consultant LTD., Heidelberg, Edinburgh, 1074-1077.

[45] Tipping, E., Hetherington, N.B., Hilton, J., Thompson, D.W., Bowles, E. and Hamilton-Taylor, J. (1985) Artifacts in the Use of Selective Chemical Extraction to Determine Distributions of Metals between Oxides of Manganese and Iron. Analytical Chemistry, 57, 1944-1946. http://dx.doi.org/10.1021/ac00286a035 